\title{
Prosopography as a Research Tool in History of Science: The British Scientific Community, 1700-1900
}

\section{Citation}

Shapin, Steven and Arnold Thackray. 1974. Prosopography as a research tool in history of science: The British scientific community, 1700-1900. History of Science 12: 1-28.

\section{Published Version}

http://www.shpltd.co.uk/index.html

\section{Permanent link}

http://nrs.harvard.edu/urn-3:HUL.InstRepos:3353816

\section{Terms of Use}

This article was downloaded from Harvard University's DASH repository, and is made available under the terms and conditions applicable to Other Posted Material, as set forth at http:// nrs.harvard.edu/urn-3:HUL.InstRepos:dash.current.terms-of-use\#LAA

\section{Share Your Story}

The Harvard community has made this article openly available. Please share how this access benefits you. Submit a story.

Accessibility 
Hist. Sci., xii (1974), 1-28

\title{
PROSOPOGRAPHY AS A RESEARCH TOOL IN HISTORY OF SCIENCE: THE BRITISH SCIENTIFIC COMMUNITY 1700-1900
}

\author{
Steven Shapin \\ University of Edinburgh \\ Arnold Thackray \\ University of Pennsylvania
}

The most venerated truism of the historical profession is that what you see depends upon where you stand and how you choose to focus your attention. In no field is this more true than in the history of science.

George Sarton was convinced that "the history of science is the history of mankind's unity, of its sublime purpose, of its gradual redemption". $\mathrm{He}$ therefore gave his energies to the task of locating, describing and evaluating each and every member of that growing throng which he believed had added to systematized positive knowledge as age succeeded age. More recently Alexandre Koyré has seen science as a high, almost Platonic, enterprise "essentially theoria, a search for the truth". Its history "reveals to us the human mind in its most noble aspect". In part owing to Koyré's influence, many historians of science are today concerned to trace the history of scientific thought, as the "itinerarium mentis in veritatem". Their line of investigation necessarily leads from seminal thinker to seminal thinker, while ignoring most of Sarton's host. A further contrast is seen in the work of Joseph BenDavid, the historical sociologist of science. Ben-David finds the organizing principle for his brilliant two hundred page survey of three millennia in "the emergence and the development of the social role of the scientist". His history is devoid both of Sarton's great throng and of Koyré's seminal minds. However, all three writers share a characteristic tendency to reify modern science, and thus to become entrapped in teleological and moralistic thinking. ${ }^{1}$

Perhaps the greatest problem the historian of science now faces is that of seeing his subject in other than presentist perspectives. The growth of systematized positive knowledge; the discovery of scientific method; the emergence of the social role of the scientist; the path to truth - each organizing principle presupposes that history as a process is interesting or important precisely in so far as it explains the appearance of science in the form we may now see it. Enormous difficulties confront any attempt to understand 
the evolution of man's enquiries into nature in other than present terms. This is not the place even to sketch that complex process by which the European approach to nature passed from its early seventeenth century position on the philosophical periphery to its late nineteenth century centrality as the very paradigm of certain knowledge. Likewise we can but note parenthetically how the major thrust of philosophical thought, from Voltaire to the Vienna Circle, has been to perceive science as something apart, unchanging in its methods, aims and structure (although not in its content), and essentially ahistorical.

The real, if latent, religious functions served by a faith displaced from Christian verities to scientific method are apparent, if unexplored. Today we may disavow George Sarton's touching belief in science as the key to man's gradual redemption. Yet that pervasive positivism which found full flower in his life and work still permeates the profession of the history of science. We have been slow to abandon those assumptions about the moral character of science, the nature of truth, and the task of the historian which derive from Comtean postulates, and have little meaning on their own. Only recently have (often unconscious) positivistic orientations slowly begun to yield to more realistic concerns about the changing meanings of natural knowledge in Western culture. ${ }^{2}$

It is almost half a century since Herbert Butterfield brilliantly demolished The Whig interpretation of history (London, 1931). Butterfield's attack on prevailing modes of political analysis was cast in the categories of intellectual history. When, two decades later, he turned to history of science, it was as intellectual history that he viewed it, though with ironic results. Such was the force of the great tradition that, in The origins of modern science (London, 1949), even Butterfield succumbed to the very Whiggism he had so rightly castigated in political analysis. Nonetheless his account made public a new standard of historical sophistication in the examination of scientific thought. Only partially as a result, the intellectual history of science has undergone rapid development. Accounts of that history in presentist and teleological (or "Whig") terms have been subject to attack for some years now. The sophisticated, complex formulations of Koyré or a Dijksterhuis have become targets, every bit as much as the robust statements of a Sarton or a Partington. In the writings of Walter Pagel, Frances Yates and their followers we have begun to glimpse new ways of viewing the systematic, dynamic interrogation of nature as an evolving and characteristically Western concern, yet one not critically dependent on 'the scientific method', 'the Scientific Revolution', 'the path to truth', or even 'science' itself in any modern meaning of the term. ${ }^{3}$

However, matters are very different when we turn to the social history of scientific activity. Professor Ben-David's recent book amply demonstrates that the social history of science is still a goal-directed enterprise. To trace 
"the emergence and the development of the social role of the scientist" is its accepted ambition, the seventeenth century its crucial locus. ${ }^{4}$ Yet the 'scientist' is himself a social construct of the last hundred years or so. And, as usually understood, so are 'science', 'the scientific community', and 'the scientific career'. To write the history of any period before ca 1870 primarily in terms of such unqualified modern categories is to endanger the enterprise at its inception and to entrench in social history those teleological assumptions now slowly disappearing from intellectual analysis.

At this juncture the historiography of political activity would once again seem to offer certain lessons. Shortly before the publication of Butterfield's Whig interpretation Lewis Namier had already shown the folly of viewing eighteenth century politics in such late nineteenth century terms as 'party' and 'democracy'.5 Namier's approach to a more adequate historical understanding was through social history. His favourite tool was that of collective biography. Namier never wrote on science. No more did any historian of science explore the liberating possibilities inherent in collective biography. ${ }^{6}$

The deceptively unselfconscious collective biography of Lewis Namier has by now been transformed and elaborated into the prosopographical analysis of Lawrence Stone and his followers. The term itself is something of a neologism and not to be found in the usual dictionaries. The Oxford English dictionary describes it as an "obsolete" word, derived from the Greek $\pi \rho o ́ \sigma \omega \pi o \nu$, meaning "face or person". As used from the late sixteenth century, it meant "a description of the person or personal appearance". Professor Stone now defines prosopography as "the investigation of the common background characteristics of a group of actors in history by means of collective study of their lives".7 Employing collective biography, modern prosopographical analysis is not the routine collected biography of the Victorians but a sophisticated tool for establishing links between action and context, akin to the 'multiple career line analysis' of the sociologists. Our use of the term prosopography, rather than 'collective biography', reflects the fact that the former stands for a coherent and well-developed technique in the study of history, with its own rules and modes of addressing itself to historical questions.

Prosopography has flourished and matured as a historical technique in fields as varied as the study of voting behaviour and social mobility. Thus Professor Stone can refer to prosopographical analysis as "one of the most valuable and most familiar techniques of the research historian", and go on to observe that among its many uses it may help "to tie the exciting developments in intellectual and cultural history down to the social, economic, and political bedrock". 8 In no field of history is this fruitful possibility more likely to follow from the application of prosopographical techniques than in the history of science. In the rest of this essay we shall therefore focus on some possibilities of prosopography as a tool for increasing our understanding 
of science and freeing our historical thinking from presentist and teleological modes. In so doing we shall not belittle or trivialize science as an enterprise or as a set of ideas. We shall rather come to an enhanced appreciation of how deeply the desire both to know and to subdue nature was bound into those transforming processes which differentiated the Western from other cultures. In particular we shall seek to show how the forms of British social and cultural life in the eighteenth and nineteenth centuries, the growth of British interest in natural knowledge, and the slow evolution of the scientific enterprise may be mutually illuminated by prosopographical analysis. ${ }^{9}$

\section{II}

The prosopographical approach is particularly suited to the study of British science in the period of urbanization and industrialization. The nation which was at the centre of a quickening interest in nature in the seventeenth century was also the scene of 'the first Industrial Revolution' in the eighteenth and nineteenth centuries. The silence about science in most economic historians' accounts of British industrialization is strange when seen against the firm conviction of so many participants that a correct understanding of nature was the driving engine of national progress. ${ }^{10}$ Economic history has not accepted this contemporary opinion of the central role of science, and such non-acceptance in part reflects that reified vision of the character of natural knowledge common in recent historical writing. As we shall argue below, the rubric of science in the eighteenth and nineteenth centuries encompassed far more than is currently allowed to the term.

Not only was its content different, but also the structure of British science remained emphatically pluralistic through the Victorian age. ${ }^{11}$ British men of science were more involved with general culture than their counterparts in countries like France and Prussia, where state patronage abetted the earlier creation of more formal scientific roles..$^{12}$ Cultural insulation, if not isolation, is a necessary concomitant of professionalization..$^{13}$ The lag in the appearance of professionalized science in Britain reflects not so much a delayed recognition of an inevitably modern condition but a national attitude towards both specialized knowledge and professional norms. As Namier once observed:

Literae Humaniores, the most English of schools, goes back to the all-round man of the Renaissance. For specialisation necessarily entails distortion of mind and loss of balance and the characteristically English attempt to appear unscientific springs from a desire to remain human.... What is not valued in England is abstract knowledge as a profession, because the tradition of English civilisation is that professions should be practical and culture should be the work of the leisured classes. ${ }^{14}$

The professionalization of the pursuit of abstract natural knowledge was never a goal of eighteenth or nineteenth century politicians or government. 
Britain remained the land of the scientific 'amateur' par excellence. The British scientific enterprise involved, at one or another level, a far greater range of social groups than in other European countries which lacked either a progressively-minded middle-class or an enlightening aristocracy. The 'modern' separation of scientific employment from other occupations and the rendering inaccessible of scientific culture to the generally literate proceeded at a slower pace, and to a greater expression of general regret, in the country of C. P. Snow. ${ }^{15} \mathrm{It}$ is thus to a broadened conception of the British scientific community in the eighteenth and nineteenth centuries that we shall eventually turn for a new perspective on the historical role of science and its contribution to change. But first we must consider some aspects of the process of industrialization in Britain.

The validity of scientific knowledge by itself hardly accounts for its very rapid assumption of primacy of place in the Western cultural hierarchy. The overwhelming majority of literate men and women, in the eighteenth century as now, were ill-equipped to assess new scientific concepts on their intellectual merits. ${ }^{16}$ Particular assumptions and beliefs sift into the wider culture in an active fashion: they either answer to broader cultural preoccupations of the time, or they make little popular impact and survive only as 'precursors' of later orientations. ${ }^{17}$ For example, we know very little about how the Newtonian cosmos of certain individual natural philosophers became the Newtonian philosophy of the salons. ${ }^{18}$ Yet what happened in the eighteenth century requires attention. The study of nature achieved its familiar position of cultural fundamentality at that time. Investigations of a wide range of other phenomena began to be defined as derivative from the model of natural philosophy at its 'hardest core'-knowledge of matter and the mathematical principles of its relations. ${ }^{19}$ Such knowledge came to be regarded as peculiarly authentic, slowly replacing theology as the fount of all that could be known with certainty. The eighteenth century, as permeated by the new Newtonian natural philosophy, was a scientific century not because very large numbers of men and women 'correctly' understood the new ideas, but because a widely-shared image of the natural world developed and the validity of that image was believed to be authenticated by the achievements of the scientific enterprise.

The perceived fact of startling progress in conceptions of nature was one aspect of the central role of science in intellectual life. Equally significant in a newly scientific age was a publicly-shared image of the scientific community. Anti-authoritarian, meritocratic, committed to and rejoicing in the ineluctable nature of progress, the 'Republic of Science' amounted, in many minds, to a tacit critique of a sustaining autocratic state. ${ }^{20}$ The congruence which could be drawn between the perceived rules and structure of the scientific community as a social system and the vision of a changed and rationally reformed society contributed to the cultural role of science as an 
engine of modernity. In Britain, where systematic government patronage played a minor role in the support of science, technological justifications were directed towards receptive patrons of science among the manufacturing, commercial and landed classes. ${ }^{21}$ Yet the wide appeal of natural knowledge as culture among progressively-minded elements in British society had more to do with the vision of a new, rational order than with any passionate commitment to the literal truth of an always acceptable technological rhetoric. We do not ourselves know how to assess the technical pay-off of pure science. We do know that the enthusiastic patrons and cultivators of science of the eighteenth century did not attempt any systematic assessment. ${ }^{22}$ But however much we may believe in or doubt the significance of scientific advance for British industrialization, we ought to recognize certain general cultural functions of science which did in fact align it with forces shaping the modern industrial age.

In this context we ought to look not at the substance of new scientific knowledge, but at the image of science as 'new culture' and as ultimately 'useful knowledge'. Throughout the eighteenth, and well into the nineteenth century, science was widely regarded in Britain as the intellectual pursuit 'open to talent'. Unlike the restrictive and feudal professions, contributions to the 'march of scientific intellect', it was believed, could be made by anyone, whatever his station in society, whether or not he held a certificate of professional approval. Thinly veiled hostility to the constituted professions, as well as to polite learning in general, frequently surfaced in organs of popular science in the early nineteenth century. The humble origins of many eminent cultivators of science were emphasized in favourable contrast to the elitist tendencies and upper-class control of other forms of culture. Thus we have this rather typical formulation from a self-taught North Staffordshire man of science in the 1830s:

What has elevated our country to its high and proud grade in the scale of nations?-The Arts and Sciences. Through which of her sons? -Many of the humble and self-taught [who] passing the boundaries of mere scholastic literature, have carefully studied the ample and instructive page of nature. ${ }^{23}$

The roll of the 'humble' in science came to form a Pantheon in the Victorian 'self-help' religion identified with the name of Samuel Smiles. Over and over again their names were repeated: Herschel, Priestley, Dalton, Davy, Faraday; among manufacturer-scientists: Watt, Boulton and Wedgwood. ${ }^{24}$ Echoing the Paracelsian-radical theme of the late Renaissance, it was constantly argued in industrializing Britain that scientific knowledge might be had by anyone sympathetically and observantly 'reading the Book of Nature'. It was even on occasion suggested that men closer to nature and to industry than the effete upper-classes might be preferentially supplied with scientific 
acumen. Science, as essentially useful knowledge, had great appeal to classes concerned with utility, and particularly with the turning of technical knowledge to economic use. But the appeal of science as a form of culture was independent of whether the argued usefulness of science was valid or not. ${ }^{25}$

Natural knowledge and the institutions in which it was fostered during the Industrial Revolution came to serve the social function of providing an entrée into culture for groups barred from or hostile towards more traditional pursuits and institutions. Science could and did appeal to legions of the ascendant industrial, commercial and professional middle-classes who, because of religion, social origin, wealth, or personal disposition, were excluded from the traditional socializing influences of Oxford, Cambridge and other lairs of polite learning. The most striking evidence of this tendency and its effect on the scientific community has been brought forward by Nicholas Hans from his study of six hundred and eighty scientists of Dictionary of national biography stature born between 1600 and $1785 .^{26}$

The time period generally identified with the Industrial Revolution witnessed a marked increase in participation in scientific culture by classes most closely associated with the industrializing process. The figures of Joseph Priestley and John Dalton came to symbolize a range of connections and parallels between science and emergent social, religious and economic forces of the period ca 1760 to $c a 1840$. Religious dissent, especially of the Unitarian and Quaker varieties, appears to have been strongly associated with membership in the scientific enterprise during the Industrial Revolution, as was bourgeois industrial status and liberal political thought. ${ }^{27}$

The importance of these associations in Britain is that they tended to ally the study of natural phenomena with a variety of forces and trends making for industrialism; there seems to have been a ramified mutual service relationship between these various elements. ${ }^{28}$ One way of assessing the role of science in this particular age thus becomes a search for the scientific community -those who participated in and supported the study of nature, not from the standpoint of the values and standards of the scientific profession, but from the standpoint of science as an ecologically well-adapted variant which answered the social and ideological needs of many whose participation in literate culture might otherwise have been non-existent.

This aspect of science as marginal culture during the British Industrial Revolution is particularly apparent in the many scientific (usually called 'literary and philosophical') societies established throughout provincial England and Scotland, especially after the 1780 s. $^{29}$ The Victorian apostle of 'self-help' Samuel Smiles said that these scientific societies "were usually centres of the best and most intelligent society of their neighbourhoods, and were for the most part distinguished by an active and liberal spirit of enquiry". 30 Such societies represented serious attempts at cultural selfexpression by the middle-classes of the new industrial towns of the Midlands 
and North. Most significant for our purpose is that these literary and philosophical societies were in fact scientific organizations, dedicated to the inculcation of scientific attitudes and principles, if not always to the intellectual advance of expert science. ${ }^{31}$ It was via natural knowledge that the urban middle-classes of the new industrial cities sought entry to British literate culture. Some of these scientific organizations, most notably the Manchester Literary and Philosophical Society, had illustrious intellectual careers, their membership rolls studded with distinguished names. Others, like the Pottery Philosophical Society of North Staffordshire, had brief life-spans, produced at most one or two men of science of D.N.B.-stature, and sank into oblivion, leaving scarcely a trace. ${ }^{32}$ But it would be misguided to assess the total cultural significance of natural knowledge by only the most successful and enduring of its institutions, or the local cultural influence of a scientific society solely in terms of its contributions to the annals of positive science.

For every recognizable name of a publishing man of science which we may detect in the records of these scientific societies we will notice possibly fifty or more individuals to whom no scientific article or book may be attributed. These latter are largely local medical men, clergy, merchants, manufacturers, lawyers, gentry and skilled artisans. ${ }^{33}$ They were not, it should be emphasized, failed scientists; they participated in and sustained the local scientific enterprise as medical men, artisans, clergy, etc. Only the exceptional individual in a typical provincial society regarded himself primarily as a man of science and attempted to manipulate the resources and interests of the local organization into a vehicle for his own career interests. In some provincial settings the scientific society provided the only philosophical apparatus or library facilities. In others it constituted a quasieducational institution. Thus the 'amateur' scientific preoccupations of a local power-elite might adventitiously supply resources for a very limited number of men who wanted to pursue science as a career. Whether the remainder of the membership contributed competent work or not, what is of importance is that it was via natural knowledge that most of them participated in literate culture at all. The contribution made by a scientific forum to the emerging values and attitudes of the audience signified as much as the intellectual work of the few performers. ${ }^{34}$

It was inter alia through association with a scientific society that many men of the provincial towns asserted cultural values which they saw as appropriate to their environment and their condition in British society. The perceived appropriateness of natural knowledge to the socio-economic setting entailed elaborately constructed justifications of scientific culture in terms of its technological and economic potential. This kind of justification was connected just as much with the Mechanics' Institutes of the mid 1820s as it was with the middle-class literary and philosophical societies which began to be established a generation or more earlier. It is not necessary for 
an understanding of the cultural uses of natural knowledge either to accept the entire validity of such justifications or to conclude that those who advanced them were disingenuous. What is manifested here is rather a politically motivated overlay for particular cultural uses of natural knowledge.

A middle-class advocate of a Mechanics' Institute for the North Staffordshire Potteries in 1825 argued that

... there is no science of so much value to a Potter as Chemistry; and yet how few of our people are even imperfectly acquainted with it. . . . Whatever the practical potter may think, it really is a disgrace to him to be ignorant of this science; nor can he calculate the negative influence which his ignorance must have in retarding the perfection of his art. The preparation of his various bodies and glazes; the application of heat to harden and vitrify them are merely the practice of a few chemical experiments, and an extended knowledge of the science would enable him to detect any impurities or adulterations in his materials . . ., sparing him the trouble and expense of absurd experiments. ${ }^{35}$

The same writer went on to urge the study of geometry for the 'journeyman potter' and anatomical classes for the modellers. Yet very few practical potters or modellers had any effective control over the processes they were paid to execute. A more convincing middle-class rationale for the scientific education of the artisan was the aspect of social control; hopefully, the worker would thereby be "rendered superior to the habits of drinking . . . by inspiring self-respect, by introducing him to new and purer pleasures, and all these without any necessary ill consequences to his superiors". ${ }^{36}$ Scientific and technical education in the Mechanics' Institutes was designed to make workers "good citizens and to teach them the nature and extent of their duties". 37

The 'civilizing' influence of the cultivation of natural knowledge was not, of course, argued solely from middle to working class. We need to remind ourselves of the frontier atmosphere and the paucity of alternative cultural outlets in the new industrial towns. There was an overwhelming concern with the problem of crime and violence. Middle-class energies were devoted not only to the direct suppression of working-class crime but, in many cases, to devising cultural forums which would elevate the general tone of the town. It appears that membership in the local scientific society served to identify the manufacturer or professional man as a member (or potential member) of the local elite, demarcating him from his more uncouth fellows. ${ }^{38}$

Wealth flowing from commercial and manufacturing sources could not be rapidly transformed into enhanced social status in the late eighteenth century British scene. The defining characteristics of the British elite classes remained, on the one hand, the ownership of land, and, on the other, the guardianship of literary culture. Participation in the alternative value-system 
of a deliberately scientific culture could render concrete (at least locally) the enhanced social standing argued by new capitalist wealth. A taste for science might "afford a grateful recess from the bustle and attention of business ... and give a man respectability and consequence". Education and the cultivation of science would enable the tradesman

to appear in the world in that line, to which an honourable ambition should prompt him to aspire. His connections will be the more advantageous. To his customers, to his friends, to his fellow citizens, to foreigners, to the world in general, he will appear with greater consequence and respectability. His advice, his example, his influence will have a weight which mere fortune, without mental cultivation, can never, of itself, command.

Natural philosophy was a suitable activity for the young sons of Manchester businessmen who had not received "that culture which their fortunes entitled them to". It was rational amusement; it might conceivably pay off in application to their line of business, and, most significantly, it would serve to distract their attentions from "the tavern, the gaming table, or the brothel".39

The culture of science, therefore, served two distinct, complementary functions in the unfamiliar industrial context. First, it became an affirmation in cultural terms of the new economic and social order. To a class whose economic power initially found no proportionate outlet to political and social power, the image of the 'Republic of Science' was peculiarly appealing. The democratic rules perceived to govern participation in the scientific enterprise could be (and often were) contrasted critically with the authoritarian and elitist political establishment of pre-Reform times. Had the French Revolution, and particularly the British reaction to the Terror, not intervened, science might have become far more strongly associated in Britain with agitation for radical social and political change. ${ }^{40} \mathrm{~A}$ further facet of the affirming role of scientific culture was its image as highly useful knowledge. In this, its empirical component and its fluid social structure were more important than any advantage to industry or agriculture that might be potentially amenable to cost-benefit analysis.

Second, participation in scientific culture might serve to demarcate those in the local setting who cultivated it from those who followed no cultural pursuit at all; or those who argued (or assumed) that deliberate culture was unnecessary for the main business at hand, the achieving of wealth. (More familiar than the scientist-manufacturer as a Victorian literary type is the self-made man of trade who never had any formal education, who despised all sorts of learning and enlightenment except the Bible, and who denied it to his thirsting children. Perhaps the classic model of the Victorian obscurantist-tradesman is Arnold Bennett's Darius Clayhanger.) Science as marginal 
culture might thus constitute a rejection of the dominant values of the novel urban industrial context. This ambivalence attached to science probably persisted through the period during which natural knowledge was still very imperfectly professionalized and during which the literate laity played an extensive role in its propagation. We may trace this process in terms of the increasing proportion of scientific professionals in British scientific societies and the associated rise of avowedly 'amateur' provincial 'natural history and archaeological societies'. ${ }^{41}$ A speculation as to the dating of the ultimate divorce between natural knowledge and general culture in Britain would seem to place it between 1870 and $1900 . .^{2}$ Whatever the case, we shall have no secure basis either for assessing the onset of professionalism in British science or for examining the putative roles of science in industrialization until we come to a much clearer understanding of the British scientific community during the eighteenth and nineteenth centuries.

\section{III}

The current appreciation of what is meant by the scientific community is clearly inadequate for such a purpose (although entirely satisfactory in the contemporary world). The insulated scientific role is a recent development, and the employment of scientists on any significant scale is even more recent. We find it convenient to speak of scientists, or even of professional scientists, in the seventeenth and eighteenth centuries when what we really mean is a set of individuals who did an historically appreciable quantity of original research into natural phenomena and for whom such research was an important component of their historical identity. Thus the third Earl of Bute probably did quantitatively more science than some men who are regarded as scientists, but, because his historical identity is that of a politician, he would not be labelled a scientist. Most historians of science who employ such labels for the period before the mid-nineteenth century do so because no other single term is as satisfactory; they are often aware of the anachronism, and are reasonably assured that no substantial number of readers will mistake their meaning. Throughout the eighteenth and nineteenth centuries a variety of terms were in use in Britain to indicate the members of a scientific community, from the virtuosi of the pre-Royal Society circle, to the natural philosophers of the early Newtonian era, and the men of science or cultivators of science of Hanoverian Britain. (The terms are not equivalent, nor are they easily definable.) In 1660 the Royal Society of London was founded "for the promotion of natural knowledge", as was the Royal Society of Edinburgh 123 years later. David Brewster, advocating the organization which emerged as the British Association for the Advancement of Science, called in 1831 for a "Society of British cultivators of science" and its founding circular called to its cause the "Friends of science". ${ }^{43}$ Our purpose here is sociological, not 
philological. The diversity of terms reflects a diversity of roles and a fluidity of social structure - not a regrettable confusion.

Through the Victorian period the conditions on which an individual participated in the British scientific enterprise were far more flexible than they became later on. People pursued investigations into natural phenomena for a variety of reasons, only one of which was that they regarded themselves as 'men of science'. For similarly varied reasons a person might patronize the cultivation of natural knowledge, its application or its dissemination. He could follow recent developments in science up to a point at which he was able to converse intelligently on the subject with persons who did totally identify themselves with scientific research; he might choose to associate himself with an organization whose primary or subsidiary function was the prosecution or encouragement of science; or he might disseminate and propagate scientific knowledge, principles or attitudes. All or any of these activities were pursued not necessarily because the individual in question thought himself a scientist, but because he saw in them some significant bearing on his existing or desired social, economic or cultural roles. The British scientific enterprise proceeded as it did on the top-most intellectual level only because of the varied involvements of very large numbers of individuals whose participation was on their terms, rather than on the terms of a nascent scientific professionalism.

Much can be learned by viewing the British scientific community as embracing the whole set of individuals participating in natural knowledge on the terms outlined above. Looked at in this way science may become a matter of greater significance to the social, economic and cultural historian. Once we begin to trace the extent of this community, its structure and functions in the larger context, we will be enabled to appreciate new facets to the development of modernity in Britain. If the modern age is truly a scientific age, we shall want to know about the contribution of scientific culture to modernization in all its aspects. This approach also has its attractions to the historian of science. Examining the scientific community thus broadly redefined, the historian of science may be in a better position to appreciate the influence of local patronage and the local audience on scientists' problem-selection, modes of enquiry, and career patterns. ${ }^{44}$

At this stage it may be helpful to venture a preliminary, and rather artificial, structuring of the British scientific community. Then, using this structuring as a guide, we will discuss the varied resources for identifying the participants in the scientific enterprise during the eighteenth and nineteenth centuries. At the first level there is the group of people who published a scientific paper, book or pamphlet. ${ }^{45}$ It seems defensible to regard the act of publishing one's thoughts or research as constituting a special level of identification with the scientific enterprise. Not all the people in this category are scientists (by any definition), but all individuals we are used to thinking of as scientists will be 
found on the publishing level. At a second level we may identify those who did not publish but who formally and actively associated themselves with a scientifically-oriented society or institution, or themselves taught or disseminated scientific knowledge. In this group we mean to include the thousands of non-publishing members of the British literary and philosophical societies, scores of science teachers in dissenting academies and ephemeral science schools throughout Britain, itinerant or extra-mural lecturers in science, and the numerous medical men, mathematical practitioners, scientific engravers, purveyors of apparatus, philosophical instrument-makers, printers and curators who abounded in metropolitan centres. The scientific expertise of individuals in this category was, in many instances, very high. Certain of them were without doubt crucial to the development of new scientific ideas through their contacts and conversations with those able or inclined to publish. Their activity may be detected through membership rolls of scientific societies, ${ }^{46}$ mention in the memoirs of publishing men of science, advertisements for scientific lectures and courses in newspapers, biographical accounts in histories of educational institutions, or in the various biographical registers and rolls to be discussed below.

Finally, at a third level we may with greater difficulty identify a large mixed bag of cultivators of science who patronized, applied or disseminated scientific knowledge or principles, but who themselves neither published science, taught science, nor actively associated themselves with scientifically-oriented institutions. For many of them, the pursuit of natural knowledge amounted to technical curiosity, cultural identification, rational amusement, or theological edification. They certainly did not identify themselves with the structured scientific enterprise but they employed science (and moral and technical derivatives of science) for their own ends. However, many of the men in this group had a profound influence on the growth of natural knowledge in Britain. One can mention King George III (friend of Sir Joseph Banks, PRS, and enthusiastic amateur of natural history and agricultural science), the third Earl of Bute (patron of science, botanist and collector of philosophical instruments), and Robert Ferguson of Raith (inactive FRS and FRSE, friend of Cuvier, John Leslie and Humphry Davy, and important collector of mineralogical specimens). But as yet, because of our current sense of the scientific community, we have very little understanding of the influence of men like these and still less of the terms on which natural knowledge was important to them. ${ }^{47}$

The prospects for the collective biography of the British scientific community are very good. Recent studies which have used collective biography as a tool for examining natural knowledge in context have yielded encouraging results. ${ }^{48}$ As a guide towards future research we shall devote the remainder of this paper to a critical assessment of the kinds of biographical sources available for the study of the British scientific community, 1700 to 1900. 
IV

We shall start by considering biographical sources for those individuals who published science. ${ }^{49}$ It should be emphasized that only a very small proportion of this group has heretofore concerned the historian of science; in fact, we have little idea just how big this group is. The first problem is therefore one of identification. How can one discover the names of all those who published science during a given time period? Certain convenient and comfortable historical crutches must be cast aside at the outset; at this level of enquiry the exclusive use of the Dictionary of national biography is clearly inadequate and, whenever it is used, it must be checked with an array of other sources. Neither will the new Dictionary of scientific biography suffice in itself. ${ }^{50}$ What we cannot do is to start with names known to us through their science; first we must find out who published science, then assess the intellectual and cultural significance of their association with the enterprise of natural knowledge.

For this purpose there is a number of surprisingly extensive and accurate bio-bibliographies available, especially for the period 1770-1830. Several of these survey both book and periodical literature and include varying amounts of biographical detail on each author listed. A particularly valuable (and little used) example is J. D. Reuss's Alphabetical register of all authors living in Great Britain ... from the year 1770 to the year 1790 (Berlin, 1791), and a Supplement for $1790-1803$ (Berlin, 1804). ${ }^{51}$ Reuss lists many thousands of authors and his Register may be combed for men of science using whatever definition of science one chooses. There is a similar, anonymously-compiled (but not rare) Biographical dictionary of the living authors of Great Britain and Ireland (London, 1816), attributed by the British Museum catalogue to John Watkins and Frederick Shoberl, which lists about six thousand names. Also extremely useful is Robert Watt's Bibliotheca Britannica (Edinburgh, 1824). Watt was a Scottish physician and, although his plan takes in authors of all times and places, it is especially rich in contemporary and eighteenth century medical and scientific writers. Almost alone of all the bio-bibliographic compilers, Watt provides a subject-index from which a list of authors in a particular scientific area may be easily culled.

Largely derivative from Watt, Reuss and the 1816 Biographical dictionary, is S. A. Allibone's Critical dictionary of English literature (Philadelphia, 1859-92). The accuracy is often poor but Allibone's is the most comprehensive British bio-bibliography of all. Also valuable in the Scottish context is the seven volume Catalogue of the printed books in the library of the Faculty of Advocates [of Edinburgh] (Edinburgh, 1863-79). It lists a number of scientific authors whose work had only limited distribution, often not appearing in the British Museum catalogue of printed books. Unlike the sources listed above, the British Museum catalogue rarely provides any significant biographical detail and often leaves one unable to distinguish between authors 
with identical names. Similarly, the Royal Society catalogue of scientific papers, whose coverage commences only in 1800 , provides no biographical information and neglects a number of ephemeral and less-established periodicals. However, using all these sources together one may easily produce a list of perhaps several thousand British authors of scientific books, papers and pamphlets for the period 1770-1830 alone. In no way do these sources present the historian with a situation in which he is obliged to study science (or a specific scientific discipline) according to an externally-imposed definition of it; he may introduce whatever qualitative or quantitative restrictions he desires.

Biographical works specifically addressed to men of science are often less helpful than the general bio-bibliographical sources. As a general biographical dictionary of scientists, J. C. Poggendorff's Biographisch-Literarisches Handwörterbuch zur Geschichte der exacten Wissenschaften (Leipzig, 1863) is unsurpassed. The first two volumes of Poggendorff cover the period up to 1858. Later numbers in the series deal with subsequent and more limited periods, and are therefore more inclusive. References to biographical sources are generally provided and the accompanying bibliographies are usually complete. ${ }^{52}$ For special scientific areas there are a number of useful biographical dictionaries. Among them are James Britten and G. S. Boulger's Biographical index of deceased British and Irish botanists (2nd ed., London, 1931) which contains the names of approximately two thousand, five hundred naturalists, some of whom did not publish; E. G. R. Taylor's Mathematical practitioners of Hanoverian England 1714-1840 (Cambridge, 1966) with over five hundred names; John Donaldson's Agricultural biography (London, 1854), an extremely interesting source which notices over five hundred men of science who wrote on agriculture-related subjects from 1480 to the mid nineteenth century; and W. R. Dawson's edition of The Banks letters (London, 1958) which, although not a biographical dictionary, provides information on hundreds of obscure naturalists and geographers who corresponded with Sir Joseph Banks from the mid eighteenth century on. In somewhat different vein, Bennett Woodcroft's Alphabetical index of patentees of inventions, 1617-1852 (London, 1854, reprinted 1969) allows technical innovation to be minutely traced.

Very many individuals who published science were not scientists by any extension of the term and will not be found in dictionaries of men of science. In order to learn something about them, and about non-publishing members of the scientific community, we shall have to turn to general biographical sources, most of which are familiar to the social historian of the period if not to the historian of science. One may seek an entry by using Theodore Besterman's $A$ world bibliography of bibliographies (4th ed., Lausanne, 1965${ }^{66)} ;{ }^{53}$ R. B. Slocum's Biographical dictionaries and related works (Detroit, 1967); P. M. Riches's Analytical bibliography of universal collected biography 
(London, 1934); or A. M. Hyamson's Dictionary of universal biography (2nd ed., London, 1951). Going from these general references to particular dictionaries, one may find helpful the depth of Victorian sources like the numerous editions of Men of the reign and Men of the time for the mid to late nineteenth century.

Among general biographical dictionaries which are especially useful in the context of eighteenth and nineteenth century Britain are Sir John Alexander Hammerton's Concise universal biography (2 vols, London, 1934-35), Alexander Chambers's General biographical dictionary (new ed., 32 vols, London, 1812-17), and Rev. Hugh Rose's $A$ new general biographical dictionary (12 vols, London, 1853). Uniquely valuable is the edition by Sir George J. Armytage of William Musgrave's Obituary prior to 1800 (Harleian Society Publs, vols xliv-xlix, London, 1899-1901) which lists references to obituary notices for thousands of authors who died before 1800. Many of the citations are of notices in periodical publications such as Gentleman's magazine and Scots' magazine. The Index Society of London has published An index to the biographical and obituary notices in the Gentleman's magazine 1731-1780 (London, 1891), and the National Library of Scotland holds a manuscript continuation of that index for the period 1791-1855 (Adv. MS. 34. 5. 23). In addition, memoirs of many literary men appear in John Nichols's Literary anecdotes of the eighteenth century (9 vols, London, 1812-16), and his Illustrations of the literary history of the eighteenth century (8 vols, London, 181758 ), both of which are available in recent facsimile reprints.

The greater spread of literacy in Scotland during this period and the relative ease of access to Scottish universities is reflected in what seems to be a disproportionate number of Scottish authors. The particular attractiveness of the Edinburgh and Glasgow schools of medicine and science from the mid eighteenth through the nineteenth century may have influenced what also appears, at first sight, to be a bias among Scottish authors towards medicine and natural knowledge. Whether this suspected bias is borne out or not by what may be a simple computer study, the social historian of ideas is fortunate in the array of Scottish biographical dictionaries which are available. Most of them give due attention to the intellectual interests of men whose reputations were made in other spheres and they provide more than adequate bibliographies. Sources of special value for the scientific aspects of the Scottish Enlightenment are William Anderson's The Scottish nation (Edinburgh, 1860-63), Robert Chambers's Biographical dictionary of eminent Scotsmen (Glasgow, 1855, and other eds), Joseph Irving's Book of Scotsmen (Paisley, 1881), and, centring on Edinburgh, Hugh Paton's edition of $A$ series of original portraits and caricature etchings by ... Fohn Kay (Edinburgh, 1838, and other eds).

Our understanding of the social and cultural uses of science in the British provincial scientific societies is still sketchy. But enough is known to suggest 
that they were important forums for the dissemination of technical information and general scientific attitudes during the Industrial Revolution. Few of the members of such organizations made enduring contributions to natural knowledge. Yet many thousands associated themselves with the scientific 'march of intellect' via the literary and philosophical societies and the Mechanics' Institutes. Histories of the provincial scientific societies are generally inadequate by modern standards, but several of them provide opportunities for examining the connection between scientific performers and the local audience for natural knowledge. Usually membership lists and capsule biographies are available. Representative of such histories are Edwin Kitson Clark's History of 100 years of life of the Leeds Philosophical and Literary Society (Leeds, 1924), F. B. Lott's Centenary book of the Leicester Literary and Philosophical Society (Leicester, 1935), R. A. Smith's A centenary of science in Manchester (London, 1883), and R. S. Watson's History of the Literary and Philosophical Society of Nerwcastle-upon-Tyne (London, 1897). Similar histories exist for almost all the London discipline societies of the nineteenth century, e.g. the Linnean, Geological, Entomological, Zoological, Geographical, Statistical and Chemical. The printed proceedings of both provincial and metropolitan scientific societies are often superb sources for identifying non-publishing members of the scientific community.

Still another entry into the collective biography of intellectuals in general is provided by university and school rolls of all sorts. Through the mid eighteenth century, especially before the rise of the Scottish medical faculties, large numbers of British students attended the University of Leyden. In addition to the matriculation roll for Leyden, ${ }^{54}$ we have Edward Peacock's Index to English-speaking students who have graduated at Leyden University (Index Society Publs, vol. xiii, London, 1883) ${ }^{55}$ and R. W. Innes Smith's English-speaking students of medicine at the University of Leyden (Edinburgh, 1932). Oxford and Cambridge are naturally well served by published biographical registers, although they by no means had a monopoly on the production of scientific authors during this period. The standard source for Cambridge is J. and J. A. Venn's Alumni Cantabrigiensis (Cambridge, 192254) and for Oxford Joseph Foster's Alumni Oxoniensis (Oxford, 1887-92). Their use may be supplemented by a number of rolls and registers for individual colleges, one example of which is W. W. Rouse Ball and J. A. Venn's Admissions to Trinity College, Cambridge (London, 1911-13). For Trinity College, Dublin, there is G. D. Burtchaell and T. U. Sadleir's Alumni Dublinensis... (1593-1860) (Dublin, 1935), and for the great English public schools there are, among many others, G. F. Russell Barker and A. H. Stenning's Record of Old Westminsters (London, 1928) and R. A. Austen-Leigh's Eton College register (Eton, 1921-27). Names of masters and students of the dissenting academies, very important for their scientific teaching before the repeal of the Test Acts, may be culled from sources 
given in Herbert McLachlan's English education under the Test Acts (Manchester, 1931). Some of these schools, such as Warrington and Daventry Academies, have detailed published histories; others have left little trace. ${ }^{56}$

- Given the influence of the Scottish universities in the education of eighteenth and nineteenth century medical men and scientific writers, it is unfortunate that only the University of Glasgow is represented by an adequate published roll. W. Innes Addison's Roll of the graduates of the University of Glasgow from 1727 to 1897 (Glasgow, 1898) has short biographical notices. Unfortunately relatively few Scottish matriculants bothered to take degrees until well into the nineteenth century. Thus one must also consult Addison's Matriculation album of the University of Glasgow from 1728 to 1858 (Glasgow, 1913), even though it has comparatively little biographical information. ${ }^{57}$ The non-medical faculties of the University of Edinburgh are covered by a disappointing Catalogue of the graduates in the Faculties of Arts, Divinity, and Law (Edinburgh, 1858, and later eds) which provides no biographical data and which omits non-graduates altogether. The remaining Scottish universities (St Andrews, and King's and Marischal Colleges, Aberdeen) all have published registers of matriculants and graduates but not of the thoroughness of those for Glasgow. University histories of Edinburgh and Glasgow are quite useful for memoirs of the professors, some of whom taught science or medicine but did not publish. James Coutts's $A$ history of the University of Glasgow (Glasgow, 1909) and Sir Alexander Grant's The story of the University of Edinburgh during its first three hundred years (London, 1884) are of greater value than more modern accounts. ${ }^{58}$

As we begin to become aware of the extent of the British scientific community during the Industrial Revolution, the significance of medical men is likely to be very great indeed. Physicians and surgeons, the majority of them university-trained, were often focal points of movements to establish literary and philosophical societies in the new industrial urban centres. ${ }^{59}$ Their orientations to rational, empirical knowledge often cast them in the role of a cultural vanguard, a force dedicated to intellectual and social enlightenment, towards which a Scottish university education may have disposed many of them. The proportion of medical men in the original Manchester Literary and Philosophical Society was thirty-seven per cent; in the Philosophical Society of Edinburgh in 1739 thirty per cent-and in 1782 over fifty per cent. Nor was this phenomenon restricted to the provinces; the Royal Society of London counted twenty per cent physicians and surgeons in 1770 and seventeen per cent in $1800 .{ }^{60}$ That medical men should have turned to natural knowledge as culture is not unusual. Nor should it surprise us that their local prestige often enabled them to carry into the scientific community many manufacturing and commercial men to whom the local medical fraternity represented enlightenment and rational attitudes. Social and intellectual historians might find it rewarding to examine provincial medical 
men as a group, giving special attention to their formal education, dispersal, and subsequent local roles in social and political reform.

Sources for the collective biography of British medical men are generally excellent. At the top-most layer there are the socially elite Fellows and Licentiates of the Royal College of Physicians of London. Many of these medical men concentrated in the London area where wealthy clients abounded, or at the watering-places of Bath, Buxton and Harrogate. A good number of them produced published science; not solely medical science, but science often reflecting the non-professional motives of rational amusement or technical curiosity. Memoirs of these elite physicians may be found in William Munk's Roll of the Royal College of Physicians (London, 1861, et seq.). V. G. Plarr's comparable Lives of the Fellows of the Royal College of Surgeons of England (London, 1930) is useful only for the period after mid nineteenth century. Two German sources are indispensable for the study of British medical men and their role in science: A. C. P. Callisen's monumental Medicinisches Schriftsteller-Lexicon der jetzt lebenden Aerzte, Wundärzte, Geburtshelfer, Apotheker und Naturforscher (33 vols, Copenhagen, 1830-45) provides some biographical and much bibliographical data on hundreds of contemporary British physicians, surgeons and apothecaries; August Hirsch's Biographisches Lexikon der hervorragenden Aerzte aller Zeiten und Volker (2nd ed., Berlin, 1929-35) concentrates on a rather more well-known group and is therefore of less value in this regard than Callisen. Some otherwise obscure provincial practitioners may be located through John Leyland's Contemporary medical men (Leicester, 1888).

Approximately 6000 MDs are catalogued in the List of Graduates in medicine in the University of Edinburgh from MDCCV to MDCCCLXVI (Edinburgh, 1867, and later eds) which provides names, nationalities and thesis titles. Members of the Royal College of Physicians of Edinburgh are listed in the Historical sketch and laws . . from its institution to 1925 (Edinburgh, 1925) and Edinburgh-qualified surgeons are catalogued in the List of Fellows of the Royal College of Surgeons of Edinburgh, from 1581 to 1873 (Edinburgh, 1874). Glasgow-qualified medical men are noticed in Alexander Duncan's Memorials of the Faculty of Physicians and Surgeons in Glasgow 1599-1850 (Glasgow, 1896) and accounts of many Scottish medical men are to be found in J. D. Comrie's History of Scottish medicine (2nd ed., London, 1932). Many Scottish medical men found careers in the British military and trading companies, the influx reaching a peak during the Napoleonic Wars. While abroad many of them prosecuted valuable research in botany, zoology, geography, meteorology and geology. The scientific roles of some of these individuals may be traced in D. G. Crawford's History of the Indian Medical Service 1600-1913 (London, 1914) and Roll of the Indian Medical Service 1615-1930 (London, 1930) and in Edward Dodwell and Samuel Miles's Alphabetical list of the medical officers of the Indian Army 1764 to 1838 
(London, 1839), as well as in F. N. L. Poynter's Commissioned officers in the medical services of the British Army, 1660-1960 (London, 1968).

The cleric-naturalist is often stereotyped as a landmark of early to mid nineteenth century British culture. Thus E. P. Thompson points to "that peculiar phenomenon of early Victorian culture, the Nonconformist minister with his hand on the Old Testament and his eye on a microscope". ${ }^{61}$ Theological edification is usually regarded as the key to his scientific curiosity. But until the role of clerics in the scientific community is more completely studied along collective biographical lines, it would be premature to identify scientific preoccupations exclusively with religious dissent (or even with special brands of religious dissent). Just as medical men may be found to be the educated cultural elite of urban industrial centres, ministers may have constituted a similar class, perhaps more important than medical men in smaller towns and rural areas. Ministers were second in significance only to medical men as scientific performers in many provincial literary and philosophical societies. Church of Scotland ministers were required to be university-educated and specifically to follow courses of mathematics and natural philosophy. The adult scientific preoccupations of Presbyterian clerics may have had as much to do with their function as rural technical extensionagents as with their desire to follow "Nature up to Nature's God". Evidence to support this speculation may be collected from the superbly informative Fasti Ecclesiae Scoticanae, edited by Hew Scott (7 vols, Edinburgh, 1915-28), which provides biographical and bibliographical sketches far superior to anything in the equivalent John Le Neve's Fasti Ecclesiae Anglicanae (Oxford, 1854, and continued in later editions) and Henry Cotton's Fasti Ecclesiae Hibernicae (Dublin, 1848-78). There are, unfortunately, no central published rolls of dissenting clergy. Many names may be located through histories of particular religious sects or works such as J. J. Green's Quaker records, being an index to the "Annual monitor" 1813-92 (London, 1894) or Robert Spear's Record of Unitarian worthies (London, 1876).

While we shall not attempt to enumerate the available biographical sources for British aristocrats, gentry, politicians, lawyers, and military men, they are in every way equal to the task. Progressive gentry were prime movers behind agricultural and industrial change in England and Scotland, and many of them, such as Archibald Cochrane, ninth Earl of Dundonald, and Thomas Butterworth Bayley of Hope Hall near Manchester, saw the cultivation of science as an adjunct to their progressive social role. In Scotland especially, technically-informed lawyers presided over agricultural and industrial improvement and exercised significant control over the careers of men of science by means of patronage and their influence on bodies making appointments to Scottish university chairs. The professional and class concerns of Scottish lawyers (closely connected to the Lowland landed gentry) often channeled the activities of men of science into areas of greatest 
interest to them. ${ }^{62}$ However, in one area, printed British biographical sources are still surprisingly inadequate. A nation which, from the Victorian period onwards, has made its manufacturers into culture-heroes still has no worthwhile roll of the great names of commerce and industry. ${ }^{63}$ In this connection, and in many of the others we have mentioned, one may turn to an array of local and regional directories, municipal histories, county bibliographies, county biographical dictionaries, and newspapers. ${ }^{64}$

$\mathrm{V}$

The major object of looking at science in the manner suggested is that we will thereby have an opportunity rigorously to assess the ways in which natural knowledge served as a key ingredient in a deep transformation of British thought, society and culture. Regarded as the exclusive preserve of expert scientists, it has indeed proved very difficult to see how enquiry into natural phenomena could have played such a role. Historiographically, we have been accustomed to disregard science as it percolates from men of science to the generally literate. It has either been dismissed as non-science, scientism (hence, irrelevant or pernicious), misunderstood science (hence, error), or popularized science (hence, trivial). In point of fact, science as people think of it and as they use it is every bit as historically important as science as scientists conceive of it.

It would be a great pity if historians of science abdicated their responsibility to examine received science and its social functions. Only when we come to appreciate the full extent of participation in the scientific enterprise will we be able to see how the history of science can profitably begin to fuse the history of ideas and the history of society. Recent work hints that we have grossly underestimated the extent to which scientific ideas, scientific principles, attitudes and modes of enquiry permeated the social structure and served important structural and dynamic purposes in the process of British industrialization. As we begin to look at natural knowledge in the varied cultural contexts in which it has flourished, we shall probably come to see that perspectives carried from the university laboratory are far from adequate to the business of history. In creating a deeper historical understanding of the scientific enterprise, prosopography is by no means an all-sufficient tool. It is nonetheless a highly promising, and as yet an insufficiently exploited, mode of conceptualization.

\section{REFERENCES}

1. For further development of these brief remarks, see Arnold Thackray and Robert K. Merton's "On discipline building: the paradoxes of George Sarton", Isis, lxiii (1972), 473-95; Thomas S. Kuhn, "The history of science", 
in David L. Sills, ed., The international encyclopedia of the social sciences (New York, 1968), xiv, 74-83; Arnold Thackray, "Science: has its present past a future?", in Roger H. Stuewer, ed., Historical and philosophical perspectives of science (Minneapolis, 1970), 112-27. See also ref. 3.

2. See especially Yehuda Elkana, "Rationality and scientific change" (forthcoming in the Proceedings of the 1973 Yväskylä conference on science and philosophy, Boston studies in the philosophy of science, ed. R. S. Cohen and M. Wartofsky).

3. See Allen G. Debus, ed., Science, medicine and society in the Renaissance (2 vols, New York \& London, 1972); Stephen Toulmin, Human understanding (Princeton, N. J., 1972); Arnold Thackray, "Scientific knowledge and its historical problems", Minerva, x (1972), 491-5.

4. Joseph Ben-David, The scientist's role in society : a comparative study (Englewood Cliffs, New Jersey, 1971), vii. See also Thomas S. Kuhn, "Scientific growth: reflections on Ben-David's 'Scientific Role' ", Minerva, x (1972), 166-78.

5. L. B. Namier, The structure of politics at the accession of George III (London, 1929).

6. The exception is of course Robert K. Merton, whose pioneering 1938 study of Science, technology $\mathscr{E}^{\circ}$ society in seventeenth century England (reprinted New York, 1970) critically depended on prosopography as a technique of enquiry. However, in the classic sociological sense, Merton was marginal to the community of historians of science, and the possibilities inherent in his approach lay dormant through three decades, for reasons partially explored in A. Rupert Hall, "Merton revisited: or science and society in the seventeenth century", History of science, ii (1963), 1-16.

7. Lawrence Stone, "Prosopography", Daedalus (Winter 1971), 46-79, p. 46. A bibliography of key sources is provided at the end of Stone's article. The subject of prosopography has been introduced to readers of this journal by J. E. McGuire, "Newton and the demonic furies: some current problems and approaches in history of science", History of science, xi (1973), 21-48 (esp. 22-27).

8. Lawrence Stone, op. cit. (ref. 7), 73.

9. Although we do not have space to discuss the matter here, it may be seen that a prosopographical approach to the history of science implicitly denies the dichotomy between 'external' and 'internal' factors and offers prospect of a release from such barren morphology. However valuable prosopography may prove to be in this connection, dissatisfaction with the dichotomy has been building for some time along quite different lines. See, for example, Barry Barnes, Scientific knowledge and sociological theory (forthcoming, London, 1974), esp. ch. v; Mary Hesse, "Hermeticism and the historiography of science: an apology for the internal history of science" in Stuewer, op. cit. (ref. 1), 134-62; S. Lilley, "Cause and effect in the history of science", Centaurus, iii (1953), 58-72.

10. See A. E. Musson's editorial introduction to Science, technology and economic growth in the eighteenth century (London, 1972), 1-68.

11. See J. B. Morrell, "Individualism and the structure of British science in 1830", Historical studies in the physical sciences, iii (1971), 183-204; Sydney Ross, "'Scientist': the story of a word", Annals of science, xviii (1962), 65-86.

12. D. S. L. Cardwell, The organisation of science in England (rev. ed., London, 1972); Joseph Ben-David, op. cit. (ref. 4), chs v-vii. 
13. See, for example, Ben-David's rather teleological treatment of 'science' and 'scientism' in eighteenth century France and England: ref. 4, 80-84, 89-93.

14. L. B. Namier, England in the age of the American Revolution (London, 1930), 16-17.

15. As late as 1862 an officer of a major scientific society, the Royal Society of Edinburgh, was vigorously arguing that admission to such organizations ought not to depend on "an artificial standard of literary and scientific distinction". Of those lacking a "professional acquaintance with science", he said "Let them come, and freely, and let us regard their adhesion to our ranks as a compliment on either side". J. D. Forbes, "Opening address [to meeting of 1st December, 1862]", Proceedings of the Royal Society of Edinburgh, v (1866), 5-6.

16. Indeed, Thomas $\mathrm{S}$. Kuhn, in his The structure of scientific revolutions (Chicago, 1962), has persuasively argued that the ultimate objectivity of successive scientific theories fails to account for the fact or the manner of their adoption by scientists, let alone by the wider public.

17. For an expansion of this general point in the context of American science, see Yaron Ezrahi, "The political resources of American science", Science studies, i (1971), 117-33, and Charles E. Rosenberg, "Science and American social thought", in D. Van Tassel and M. G. Hall, (eds), Science and society in the United States (Homewood, Illinois, 1966), 135-62.

18. Beside the classic work of Peter Gay on the Enlightenment, see M. C. Jacob, "The Church and the formulation of the Newtonian world-view", fournal of European studies, i (1971), 128-48.

19. Thus one obvious and persuasive, though ultimately sterile, task was to subsume chemistry under this model. See Arnold Thackray, Atoms and powers : an essay on Newtonian matter-theory and the development of chemistry (Cambridge, Massachusetts, 1970).

20. This point is made in the French context by Roger Hahn, The anatomy of a scientific institution: the Paris Academy of Sciences, 1666-1803 (Berkeley, 1971), ch. ii. See also Ben-David, op. cit. (ref. 4), 82-83, 85-86, 89-94. It is also an important theme of Robert Merton's Science, technology and society (ref. 6). For its rather different implications for provincial England, see Arnold Thackray, "Natural knowledge in cultural context: the Manchester model", forthcoming in American historical review, lxxix (1974).

21. Aspects of the economic justification of science during the Industrial Revolution are explored by Roy Porter, "The Industrial Revolution and the rise of the science of geology", in M. Teich and R. M. Young (eds), Changing perspectives in the history of science (London, 1973), 320-43 ; and by Steven Shapin, "The Pottery Philosophical Society, 1819-35: an examination of the cultural uses of provincial science", Science studies, ii (1972), 311-36.

22. See Peter Mathias, "Who unbound Prometheus? Science and technical change, 1600-1800", in Mathias (ed.), Science and society 1600-1900 (Cambridge, 1972), 54-80.

23. Simeon Shaw, The chemistry of pottery (London, 1837), 8. Note the change in the social locus of anti-scholastic rhetoric from the seventeenth century leisured 'virtuoso' to the nineteenth century man of industry. See also Arnold Thackray, "The Industrial Revolution and the image of science" in E. Mendelsohn and A. Thackray (eds), Science and values: patterns of tradition and change (New York, 1973), 5-22. 
24. This list is taken from Shaw (ref. 23) and similar texts, but lists of this sort may be found very generally in the early to mid nineteenth century, sometimes stretching the point to include men of science from families in quite comfortable circumstances, e.g. Joseph Black.

25. The usual framework in which the debate over the technological usefulness of science is cast is one in which contemporary science either can or cannot be specifically associated with given pieces of contemporary technology. Charles C. Gillispie, "The natural history of industry", Isis, xlviii (1957), 398-407, and "The discovery of the Leblanc process", ibid., 152-70, argues the con; Robert E. Schofield, "The industrial orientation of science in the Lunar Society of Birmingham", ibid., 408-15, argues the pro. See also the selections in A. E. Musson, ed., op. cit. (ref. 10), and A. E. Musson and Eric Robinson's massive documentation of a modified pro line in Science and technology in the Industrial Revolution (Manchester, 1969).

26. New trends in education in the eighteenth century (London, 1951), 31-36. The inadequacy of relying on the D.N.B. for this sort of study will be briefly discussed below.

27. See Arnold Thackray, op. cit. (ref. 20) and Fohn Dalton : critical assessments of his life and science (Cambridge, Massachusetts, 1972). The influence of local context on membership in the scientific enterprise is illustrated by the very different situation in Edinburgh. See Steven Shapin, "Property, patronage and the politics of science: the founding of the Royal Society of Edinburgh", British journal for the history of science, vii (1974), 1-41.

28. A relationship discussed in general terms by Ernest Gellner, Thought and change (London, 1964), esp. 35, 179-80.

29. A general overview of scientific societies is given by Robert E. Schofield, "Histories of scientific societies: needs and opportunities for research", History of science, ii (1963), 70-83. Information about British provincial literary and philosophical societies may be found in Thomas Kelly, $A$ history of adult education in Great Britain (Liverpool, 1970), 107-09, 112-15; J. W. Hudson, The history of adult education (London 1851); a list of such societies is in A. Hume, The learned societies and printing clubs of the United Kingdom (London, 1847). See also ref. 32.

30. Samuel Smiles, Boulton and Watt (London, 1865), 367-8, cited by Eric Robinson, "The Derby Philosophical Society", Annals of science, ix (1953), 359-67, p. 359.

31. It is noteworthy that while many provincial societies were established to encompass "all branches of science, erudition and taste", they by and large became scientific societies within several decades. This was certainly the case with the Manchester Literary and Philosophical Society, the Royal Society of Edinburgh and the Royal Irish Academy. Factors which may account for this include a higher local approval of scientific culture, the greater energy and entrepreneurship of scientific performers, and the suitability of the organizations' general format to scientific productions.

32. A number of centenary histories of British provincial societies are listed in section IV below. Recent studies of these organizations include Arnold Thackray, op. cit. (ref. 20) and "Medicine, manufacturers and Manchester men", forthcoming in Proceedings of the XIIIth international congress of the history of science (Moscow, 1971); A. D. Orange, "The British Association for the Advancement of Science: the provincial background", Science studies, i (1971), 315-29; "The origins of the British Association for the Advancement 
of Science", British journal for the history of science, vi (1972), 152-76; Philosophers and provincials : the Yorkshire Philosophical Society from 1822 to 1844 (Yorkshire Philosophical Society, 1973); Steven Shapin, op. cit. (refs. 21, 27), and "The Royal Society of Edinburgh: a study of the social context of Hanoverian science" (unpublished Ph.D. thesis, University of Pennsylvania, 1971). Morris Berman's work on the Royal Institution of London also emphasized the provincial direction of a metropolitan organization: "The early years of the Royal Institution 1799-1810: a re-evaluation", Science studies, ii (1972), 205-40; "Social change and scientific organization: the Royal Institution, 1799-1810" (unpublished Ph.D. thesis, The John Hopkins University, 1971).

33. The proportions of the various categories differ markedly from one provincial society to another. Gentry were both numerous and influential in the Royal Society of Edinburgh, constituted only eight percent of the founders of the Manchester Literary and Philosophical Society, and were almost totally absent from the Pottery Philosophical Society. Similarly, manufacturers of china and earthenware made up the majority of Pottery Philosophical Society members; manufacturers and merchants of all types made up almost half of the early nineteenth century Manchester Society, but were a negligible group in the Royal Society of Edinburgh. Also see ref. 60.

34. The distinction between 'performer' and 'audience' in scientific societies is a very useful organizing principle in assessing the cultural significance of natural knowledge. While the scientific productions of the few performers provide the stuff for the history of scientific ideas (considered in themselves), the reception of such performances by the relevant audience is the problem which leads us to look at the role of scientific activity in the process of cultural change.

35. "Patriot", letter to editor of Pottery Mercury [Hanley, North Staffordshire], 12 October 1825. Cited in Shapin, op. cit. (ref. 21), 331.

36. Anonymous letter to editor, ibid., 28 September 1825. Cited in Shapin, ibid., 333.

37. "Caveat", letter to editor, ibid., 21 September 1825. Cited in Shapin, ibid., 333. On science in the Mechanics' Institutes, see Brian Simon, Studies in the history of education 1780-1870 (London, 1960); Mabel Tylecote, The Mechanics' Institutes of Lancashire and Yorkshire before 1851 (Manchester, 1957); and also Kelly and Hudson, op. cit. (ref. 29).

38. In the Pottery Philosophical Society, for example, many of the manufacturermembers were also closely associated with the Society for the Prosecution of Felons, Central Savings Banks for workers, agitation for Parliamentary Acts for municipal police and lighting, and, later, with the Mechanics' Institute. Members of the Manchester Society sponsored the 'lying-in' and 'lock' hospitals, street widening, the Portico library and the Society for the Abolition of the Slave Trade. See Shapin, op. cit. (ref. 21) and Thackray, op. cit. (ref. 20).

39. Thomas Barnes and Thomas Henry, as quoted in Thackray, op. cit. (ref 20). For an analogous defence of the study of natural history in the Edinburgh context, see William Smellie, The philosophy of natural history (Dover, New Hampshire, 1808; orig. publ. Edinburgh, 1790), 7-8: "It is a source of interesting amusement, prevents idle or vicious propensities, and exalts the mind to a love of virtue and of rational entertainment. ... This knowledge will be a perpetual and inexhaustible source of manly pleasures; it will afford innocent 
and virtuous amusement, and will occupy agreeably the leisure or vacant hours of life". Also see Shapin, op. cit. (ref. 21), 319.

40. As it was, natural philosophy in Britain did, to a certain extent, become involved in the domestic reaction to the 'French Philosophy' and to 'free-thinking' in general. See J. B. Morrell, "Professors Robison and Playfair, and the Theophobia Gallica : natural philosophy, religion and politics in Edinburgh, 17891815", Notes and records of the Royal Society, xxvi (1971), 43-63; Norton Garfinkle, "Science and religion in England 1790-1800", Fournal of the history of ideas, xvi (1955), 376-88; and also the numerous accounts of the 1791 Priestley riots.

41. Very little has been written about these societies (also known as 'field clubs'). Although several such organizations were founded before the mid nineteenth century, the greatest number appeared during the 1860s, 1870s and 1880s. The scope of their scientific interest was almost always local and their general purpose was to establish natural history and archaeology as 'genteel' avocations rather than to contribute to the advance of esoteric scientific knowledge. For a society founded in the 1870 s, see Michael D. Stephens and Gordon W. Roderick, "Science training for the nineteenth century English amateur: the Penzance Natural History and Antiquarian Society", Annals of science, xxvii (1971), 135-41; for an earlier society, which changed in character during the nineteenth century, see T. Russell Goddard, History of the Natural History Society of Northumberland, Durham and Newcastle-upon-Tyne, 1829-1929 (Newcastle-upon-Tyne, 1929).

42. By the early 1880 s British scientists were suffering a massive assault on their 'arrogance' and the inaccessibility of their esoteric knowledge. In some quarters the scientific community was accused of attempting to supplant traditional theological and intellectual loyalties by a 'priestcraft of science'. The appearance of such criticism may be taken as a landmark of cultural divorce. See Roy M. MacLeod, "Resources of science in Victorian England: the Endowment of Science movement, 1868-1900", in Peter Mathias (ed.), op. cit. (ref. 22), 111-66 (esp. 151-54).

43. O. J. R. Howarth, The British Association for the Advancement of Science: a retrospect, 1831-1931 (2nd ed., London, 1931), 13, 15.

44. This approach is taken to the study of the influence of progressively minded local gentry on the Edinburgh school of geology by Shapin, op. cit. (ref. 32), 236-53, 285-96.

45. We shall argue below that the printed sources permit the historian to establish whatever criteria he wishes for the 'scientific' nature of a publication.

46. Among the $\mathbf{4 9 5}$ ordinary Fellows of the Royal Society of Edinburgh elected from 1783 to 1820 , only fortyfour percent were at all active in the society, only twentysix percent read papers to the Society, and an even smaller percentage published papers in the Transactions. See Shapin, op. cit. (ref. 32), 309.

47. Almost needless to say, we recognize significant overlap between these artificial categories and intend no hierarchical significance by the ordering of levels.

48. Of the recent studies which have adopted the prosopographical approach to the social context of British science, Shapin's and Thackray's are the largest in scale. Shapin's work includes all 495 ordinary Fellows of the Royal Society of Edinburgh elected from 1783 to 1820 . Thackray's ongoing study of the Manchester Literary and Philosophical Society deals with 589 members over a longer period of time. Berman's study of the Royal Institution's Board of Governors examined a smaller sample (ref. 32). See also Bonnie and Vern 
Bullough, "Intellectual achievers: a study of eighteenth-century Scotland", American journal of sociology, lxxvi (1971), 1048-63; Vern and Bonnie Bullough, "The causes of the Scottish medical Renaissance of the eighteenth century", Bulletin of the history of medicine, xlv (1971), 13-28.

49. We are concerned here only with printed sources. Our intent is not in any way to de-emphasize the value of manuscript sources but to illustrate just how much may be learned from relatively accessible non-manuscript material. In the bibliographical essay which follows we make no attempt to be comprehensive and we have made a selection of sources which we believe to be the most useful of their kind. On manuscript sources for British men of science, see R. M. MacLeod and J. R. Friday, Archives of British men of science (London, 1972) and the bibliography in the same authors' "The quest for archives of British men of science", History of science, xi (1973), 8-20.

50. The Dictionary of scientific biography is being edited under the auspices of the American Council of Learned Societies, editor-in-chief, C. C. Gillispie. When finished it will consist of twelve volumes, treating scientists of all times and nations. Seven volumes have appeared to date. From them it appears that every included British man of science for the period is also to be found in the $D . N . B$. Other biographical dictionaries of men of science include: Allen G. Debus (ed.), World who's who in science (Chicago, 1968) and Trevor I. Williams, A biographical dictionary of scientists (London, 1969).

51. There is also a German edition called Das gelehrte England.

52. Mention must also be made in this connection of the very valuable 'Isis' cumulative bibliography, edited by Magda Whitrow (London, 1971). The section on "Personalities" in the first two volumes leads one to a massive secondary literature on men of science, many of lesser stature.

53. Especially the section on "Biography" in vol. $\mathrm{i}, 849-61$.

54. Album studiosorum Academiae Lugduno Batavae, MDLXXV-MDCCCLXXV, compiled by W. N. Du Rieu (The Hague, 1875).

55. Actually mistitled; it is an index to all matriculants.

56. See the appendix of Hans, op. cit. (ref. 26) for a list of masters teaching at dissenting academies.

57. As an example of the kind of study which may be done with the Glasgow University sources, see W. M. Mathew, "The origins and occupations of Glasgow students, 1740-1839", Past and present, xxxiii (1966), 74-94.

58. For a guide to sources for nineteenth century British universities, see Harold Silver and S. John Teague, The history of British universities 1800-1969, excluding Oxford and Cambridge: a bibliography (Research into higher education monographs, no. xiii, London, 1970). Also useful in this connection is H. Raven-Hart and Marjorie Johnston, "Bibliography of the registers (printed) of the universities, inns of court, colleges and schools of Great Britain and Ireland", Bulletin of the Institute of Historical Research, ix (193132), 19-30, 65-83, 154-70; x (1932-33), 109-13; now partially updated by Phyllis M. Jacobs, Registers of the universities, colleges and schools of Great Britain and Ireland (London, 1964).

59. Thackray, op. cit. (ref. 32).

60. Data for the Royal Society of London are from Sir Henry Lyons, The Royal Society 1660-1940 (Cambridge, 1944), 342; for Edinburgh, from Shapin, op. cit. (ref. 32), 107, 317; for Manchester, from Thackray, op. cit. (ref. 20). The less significant Pottery Philosophical Society had just eight physicians

\section{Provided by the NASA Astrophysics Data System}


(2nd ed., Leicester, 1966); Arthur L. Humphreys, $A$ handbook to county bibliography (London, 1917); Jane E. Norton, Guide to the national and provincial directories of England and Wales (London, 1950); C. W. F. Goss, The London directories, 1677-1855: a bibliography (London, 1932). The indexes to the Victoria county history also make a good starting point.

\section{Provided by the NASA Astrophysics Data System}

